\title{
Effect of priming technique and single intubating dose technique on rapid sequence intubation with rocuronium using train of four monitoring
}

\author{
Anisha Puri ${ }^{1}$, Manisha Bhatt Dwivedi² ${ }^{*}$, Sapna Bansal ${ }^{3}$, Seema Tikku ${ }^{4}$ \\ ${ }^{\mathbf{1}}$ Assistant Professor, ${ }^{2}$ Professor and HOD, ${ }^{\mathbf{3}}$ Associate Professor, ${ }^{4}$ Senior Resident, Dept. of Anaesthesiology, Maharishi Markandeshwar \\ Institute of Medical Sciences and Research, Mullana, Haryana, India
}

*Corresponding Author: Manisha Bhatt Dwivedi

Email: anishabehal@gmail.com

Received: $5^{\text {th }}$ February, 2019

Accepted: $5^{\text {th }}$ March, 2019

\begin{abstract}
Aim: Rocuronium bromide has fastest onset time among non- depolarizing muscle relaxants; hence a safe alternative for RSI when the priming principle is used. The primary aim of this study was to compare the intubating conditions with priming technique and single intubating dose technique with rocuronium and to assess the onset time of rocuronium using Train of Four (TOF) monitoring.

Materials and Methods: We conducted a randomized, prospective study in 60 patients of ASA I and II in age group of 20-50 years posted for surgeries under general anesthesia and divided into two groups of 30 each. In Group I priming was done with 1 ml of normal saline and Intubating dose of rocuronium $0.6 \mathrm{mg} / \mathrm{kg}$ was given. In group II priming was done with $1 / 10^{\text {th }}$ i.e $0.06 \mathrm{mg} / \mathrm{kg}$ (1 ml) of the total intubating dose followed by remaining dose of $0.54 \mathrm{mg} / \mathrm{kg}$. In both the groups intubating doses of rocuronium were diluted to $10 \mathrm{ml}$ of normal saline. TOF stimuli was used to assess the time of onset of intubation and Cooper scoring system was used to compare the intubating conditions.

Results: Patients intubated in the priming group showed a faster onset time $(61.97 \mathrm{sec})$ than single intubating dose group (114.57) with successful intubation in both the groups. Excellent intubating conditions were seen in $97 \%$ patients and good intubating conditions in $3 \%$ patients of both the groups.

Conclusion: Both priming technique and single intubating dose technique produces excellent intubating condition in majority (97\%) of the patients with priming technique showing rapid onset time compared to single intubating dose technique.
\end{abstract}

Keywords: Rocuronium, Priming, Time of intubation, Intubating condition.

\section{Introduction}

Rapid sequence intubation (RSI) technique is of utmost significance in patients vulnerable to aspiration such as full stomach, intestinal obstruction and general anaesthesia for emergency or elective caesarean section. The risks involved in RSI are failure to ventilate, heart rate changes, blood pressure variations and airway trauma. To avoid such undesirable side effects a modification of standard RSI technique has come up that includes preoxygenation, induction, cricoid pressure and gentle positive pressure ventilation. Modified RSI allows anaesthetist to confirm the ability to ventilate and to decide for awake intubation if ventilation failure occurs.

Succinylcholine (Sch), a depolarising muscle relaxant was the drug of choice for $\mathrm{RSI} .{ }^{1}$ It produces profound muscle relaxation but has many undesirable side effects ${ }^{2-4}$ that are related to the depolarising action of Sch. Hence nondepolarising muscle relaxants (NDMR) and newer techniques have evolved for rapid and smooth induction. But onset of action of NDMR is slow. So different approaches like increasing the single intubating dose of NDMR, combination of relaxants, priming dose, increased concentration of inhalational and intravenous agents are in use to potentiate neuromuscular blockade. ${ }^{4}$ One such technique is timing technique where a single bolus dose of muscle relaxant is administered and the period from induction to complete muscle relaxation is noted. Rocuronium bromide has the fastest onse time among non depolarisers. When used with priming technique, it can be considered as an alternative to succinylcholine. In priming technique, a small dose (1/10th) of non depolarising drug which should not cause any unpleasant side-effects is used. ${ }^{5}$ After 2-4 minutes of this small dose, a greater intubating dose produces suitable condition for endotracheal intubation. ${ }^{6}$ While using either priming dose or single intubating dose technique for accuracy, precision and minimal instability, Train of four monitoring (TOF) is helpful in rapid sequence intubation (RSI) in anaesthetised patients. It was first described by Ali et al in $1970 .{ }^{7}$ Onset of neuromuscular block is assessed by TOF stimulus with loss of visual response of adductor pollicis muscle by stimulating ulnar nerve which is the best site for monitoring. In this study, we evaluated the technique most suitable to achieve optimum conditions for rapid sequence intubation using train of four monitoring and rocuronium as muscle relaxant. 60 patients of ASA I or II in age group of 18-60 years, scheduled for surgeries under general anaesthesia were taken and divided randomly into 2 groups of 30 each. In Group I i.e timing or single bolus intubation technique, priming was done with $1 \mathrm{ml}$ of normal saline followed 3 mins later by IV rocuronium $0.6 \mathrm{mg} / \mathrm{kg}$ bolus. In Group II, Priming was done with IV rocuronium $0.06 \mathrm{mg} / \mathrm{kg}$ followed 3 minutes later by rest of the total dose $0.54 \mathrm{mg} / \mathrm{kg}$.

\section{Materials and Methods}

Our study was conducted in anaesthesia department of Maharishi Markandeshwar Institute of Medical Sciences and Research Hospital after approval of institution Ethical committee. Patients selected for the study were briefed about the method and nerve stimulation technique; written 
informed consent was taken. Investigations were carried out one day before the surgery. On the operative day, in operating room wide bore intravenous cannula was secured and lactated ringer initiated. Baseline monitoring like ECG, NIBP, SpO2 and $\mathrm{EtCO}_{2}$ was done. We noted the baseline parameters. Peripheral nerve stimulator was used to set a supramaximal stimulus. 10mins before giving the priming dose, patients in both the groups were given Inj butorphanol $30 \mathrm{mcg} / \mathrm{kg} \mathrm{IV}$, inj midazolam $0.03 \mathrm{mg} / \mathrm{kg}$ IV and Inj glycopyrrolate $0.2 \mathrm{mg}$ IV $10 \mathrm{~min}$ prior to the priming dose.

In Group I priming was done with $1 \mathrm{ml}$ of normal saline and Intubating dose of rocuronium $0.6 \mathrm{mg} / \mathrm{kg}$ was given. In group II priming was done with $1 / 10^{\text {th }}$ i.e $0.06 \mathrm{mg} / \mathrm{kg}(1 \mathrm{ml})$ of the total intubating dose followed by remaining dose of $0.54 \mathrm{mg} / \mathrm{kg}$. In both the groups intubating doses of rocuronium were diluted to $10 \mathrm{ml}$ of normal saline.

After priming, patients were enquired for having any complaints of ptosis, diplopia, dysphagia, dyspea, myalgia by the investigator who was blinded to the study. Three minutes after giving the priming dose, inj Etomidate 0.3 $\mathrm{mg} / \mathrm{kg} \mathrm{I} / \mathrm{V}$ and intubating dose of rocuronium was given for induction following which we performed modified rapid sequence intubation.

On the ulnar nerve at the wrist, a supramaximally set TOF stimuli was applied after giving the intubating dose of rocuronium. Testing at $10 \mathrm{~mA}$ above the lowest current at which four responses can be elicited provided values that are consistent with those of supramaximal testing. We repeated TOF every $10 \mathrm{sec}$ and noted till the disappearance of $\mathrm{T}_{1}$ of TOF. "Onset time of intubation." was the time lag in giving the intubating dose and the disappearance of $\mathrm{T}_{1}$ of TOF.

After $\mathrm{T}_{1}$ was lost, endotracheal intubation with modified RSI technique was done and intubation score was recorded. Intubating conditions were graded as excellent if intubating scores were between 8- 9, good with 6-7, fair with 3-5 and poor with 0-2.
Cooper et al scoring system

\begin{tabular}{|c|c|c|c|}
\hline Score & Jaw relaxation & $\begin{array}{c}\text { Vocal } \\
\text { cord }\end{array}$ & $\begin{array}{c}\text { Response to } \\
\text { stimulation }\end{array}$ \\
\hline 0 & $\begin{array}{c}\text { Poor } \\
\text { (impossible) }\end{array}$ & Closed & $\begin{array}{c}\text { Severe cough or } \\
\text { bucking }\end{array}$ \\
\hline 1 & $\begin{array}{c}\text { Nominal } \\
\text { (difficult) }\end{array}$ & Closing & Mild cough \\
\hline 3 & $\begin{array}{c}\text { Moderate } \\
\text { (fair) }\end{array}$ & Moving & $\begin{array}{c}\text { Slight } \\
\text { diaphragmatic } \\
\text { Movement }\end{array}$ \\
\hline Good & Open & None \\
\hline
\end{tabular}

Monitoring was done with $\mathrm{SpO}_{2}$, ECG, NIBP and $\mathrm{EtCO}_{2}$. Onset time of intubation, intubating score and intubating conditions at the time of intubation was noted. Anaesthesia was maintained by $\mathrm{O}_{2}, \quad \mathrm{~N}_{2} \mathrm{O}$ (50:50), inhalational anaesthetics and NDMR. Patients were reversed after culmination of surgery with Inj neostigmine $0.05 \mathrm{mg} / \mathrm{kg}$ IV and Inj glycopyrrolate $0.01 \mathrm{mg} / \mathrm{kg}$ IV. Later on patients were shifted to recovery room for further monitoring.

\section{Statistical Analysis}

The data was entered in excel sheet and then analysed using SPSS (Statistical Package for the Social Science) 21 version. Statistical analysis was done for all quantitative variables in each group. Range, standard deviation ( \pm SD), median, frequencies and percentages were compared between the groups. Student $\mathrm{t}$ - test and Maan- Whitney U test was used for independent samples for parametric and non-parametric data. Repeated ANOVA test was used for calculating difference between time periods. Chi square test $(\chi 2)$ was performed for comparing categorical data. P-value of less than 0.05 was considered statistically significant.

\section{Observations and Results}

Table 1: Distribution of patient according to age and weight

\begin{tabular}{|l|c|c|c|c|c|c|}
\hline & \multicolumn{2}{|c|}{ Group I } & \multicolumn{2}{c|}{ Group II } & \multirow{2}{*}{ T } & \multirow{2}{*}{ P-Value } \\
\hline & Mean & SD & Mean & SD & & \\
\cline { 1 - 4 } Age (in Years) & 31.47 & 12.06 & 36.33 & 11.16 & -1.622 & 0.110 \\
\hline Weight (in KG) & 61.03 & 10.91 & 58.13 & 14.00 & 0.895 & 0.375 \\
\hline
\end{tabular}

Table 2: Intubating conditions

\begin{tabular}{|l|c|c|c|c|}
\hline & & \multicolumn{2}{|c|}{ Group } & \multirow{2}{*}{ Total } \\
\hline \multirow{2}{*}{ Intubating Conditions } & & I & II & \\
\cline { 2 - 5 } & Excellent & 29 & 29 & 58 \\
\hline Total & Good & 1 & 1 & 2 \\
\hline
\end{tabular}

Table 3: Onset time and intubating score

\begin{tabular}{|l|c|c|c|c|c|c|}
\hline & \multicolumn{2}{|c|}{ Group I } & \multicolumn{2}{c|}{ Group II } & \multirow{2}{*}{ T } & \multirow{2}{*}{ P-value } \\
\hline & Mean & SD & Mean & SD & & \\
\hline Onset Time (In Seconds) & 114.57 & 15.66 & 61.97 & 7.84 & -6.565 & 0.000 \\
\hline Intubating Score & 8.67 & 0.55 & 8.77 & 0.50 & -0.853 & 0.394 \\
\hline
\end{tabular}




\section{Results}

The patients were demographically similar in both groups (Table 1). Both groups had excellent intubating condition in 29 patients $(97 \%)$ while 1 patient $(3 \%)$ had good intubating condition and none of the patient showed fair and poor intubating conditions in either of the group (Table 2). The mean onset time recorded in single intubating technique i.e. Group I was 114.57 while in Group II i.e. in priming technique 61.97 seconds was the onset time. There was a highly significant difference between the two groups with a p value of 0.000 (Table 3). Mean Intubating score in Groups I and II were 8.67 and 8.77 respectively, which was comparable with non significant $\mathrm{p}$ value.

\section{Discussion}

General anaesthesia leads to blunting of the protective reflexes in anaesthetized patients and makes them susceptible to gastric regurgitation. Rapid sequence induction (RSI) and intubation is required to prevent aspiration and emergency protection of airway in patients with haemodynamic imbalalance, difficult gas exchange and surgical emergencies. ${ }^{8}$ We opted for modified RSI because it permits positive pressure ventilation and decreases the chance of fall in $\mathrm{SpO}_{2}$ hence avoiding hypoxia. ${ }^{9}$

The induction-intubation time needs to be minimized; hence an agent which has fast onset of action and is short acting is required for RSI. Succinylcholine (Sch) has been the gold standard muscle relaxant used in RSI as it has an onset of 40-60 seconds and duration of 6-10min. But it has undesirable problems associated with it $^{10}$ like myalgia due to muscular fasciculations, hyperkalaemia, masseter spasm, bradycardia, increase in potassium levels increasing the risk of cardiac arrest, malignant hyperthermia with increased intracranial, intra-ocular, and intragastric and intracranial pressures $^{11}$ There is contraindication to use Sch in neuromuscular diseases, crush injuries and in burns. ${ }^{12}$ These negative effects succinylcholine have prompted to search for its alternatives and increased use of NDMR.

Non depolarising agents like pancuronium, vecuronium and atracuronium do not achieve acceptable intubating conditions as rapidly as Sch. ${ }^{12}$ Rocuronium is the fastest acting NDMR which is believed to be primarily due to its low potency. ${ }^{13,14}$

Rocuronium is the only certified NDMR which can be used instead of Sch for intubation due to its fast onset of action $^{15}(60-90 \mathrm{sec})$ and intubating conditions that are similar to that of $\mathrm{Sch}^{12}$ but it has a longer duration of action. The only condition where it is contraindicated is hypersensitivity reaction. But it should be carefully used in patients of myasthenia gravis, liver disease and severely cachexic patients, as the time of action of rocuronium may be drastically prolonged. ${ }^{16}$

Studies of RSI intubations using etomidate with rocuronium or succinylcholine showed comparable results at first intubation attempts. ${ }^{17}$

Rocuronium has become a popular substitute of sch for RSI in view of the side effects of sch, especially with the introduction of suggamadex. ${ }^{18,19}$ It has a rapid onset time, good cardiovascular stability and causes no histamine release. $^{20}$ Dose of Rocuronium of $0.6-1.2 \mathrm{mg} / \mathrm{kg}$ is comparable to Sch $1 \mathrm{mg} / \mathrm{kg}$ in providing acceptable intubation conditions. ${ }^{15}$ Increasing the doses will produce neuromuscular block lasting for a longer time. Sudha $\mathrm{P}$ et al observed a duration of action of $37.9 \pm 6.1$ minutes with $0.6 \mathrm{mg} / \mathrm{kg}$ rocuronium i.e duration of action is increased by 3.75 times that of Sch. ${ }^{27}$ Chavan et al found that $0.9 \mathrm{mg} / \mathrm{kg}$ rocuronium has an action for $49.3+8.7 \mathrm{~min}$ i.e. prolongs it by 7.5 times that of Sch. ${ }^{15}$ This is undesirable in case of short and medium duration surgeries. We took $0.6 \mathrm{mg} / \mathrm{kg}$ as intubating dose of rocuronium as was taken by Chathrath Veena et al who postulated that intubating conditions were similar with Sch $2 \mathrm{mg} / \mathrm{kg}$ and rocuronium $0.6 \mathrm{mg} / \mathrm{kg}$ at $60 \mathrm{s.}^{23}$

Different methods are in use to decrease reduce the onset time of intubation along and to provide satisfactory intubating conditions that are helpful in rapid sequence intubation. These methods include combining the muscle relaxants, timing principle, priming principle and large dose NDMR. Larger doses of rocuronium as used in timing technique delay recovery and needs proper adjustment of induction times to avoid side effects. Priming principle is one of the techniques where a little dose (10\% of intubating dose) of NDMR is given followed by a greater dose for intubation after 2-4 min. This fastens the onset of neuromuscular block along with adequate intubating conditions for endotracheal intubation without undue prolongation of action or undesirable side effects. This technique is preferable in all patients who required rapid sequence intubation and in whom succinylcholine is undesirable. ${ }^{6}$

In our study, rocuronium has been used with intubation dose of $0.6 \mathrm{mg} / \mathrm{kg}$ (i.e. 2xED95) and priming dose of 0.06 $\mathrm{mg} / \mathrm{kg}$ at a priming interval of $3 \mathrm{~min}$. Yavascaoglu et al observed quicker onset time and better intubating conditions with priming interval of $3 \mathrm{~min}$ as compared with $2 \mathrm{~min}$ interval. ${ }^{21}$ Sridhar et al also got better results with 3 minutes priming interval than 2 minutes. ${ }^{22}$

Kwon et al observed that the modified rapid sequence intubation (RSI) with rocuronium had similar intubation conditions and similar complications as those of conventional RSI with Sch. ${ }^{24}$

It is postulated that a little dose of NDMR blocks many acetylcholine receptors at the neuromuscular junctions (NMJ) before clinical reduction in neuromuscular transmission. The second greater dose blocks the rest of the receptors leading to faster drug onset. While the priming principle is applied to fasten Neuromuscular block is hastened by priming principle where the prior small dose is $10 \%$ of the intubating dose. The priming method is better than the bolus/timing method in all planned cases and in cases where Sch is CI. ${ }^{6}$

Studies by Griffith et al \& Rao et al established that priming principle applied to Rocuronium decreased the onset time by $42 \%$ and $46 \%$ respectively., ${ }^{4,26}$

Most of the studies prove that onset of action of Rocuronium is decreased using the priming principle but the amount of reduction in onset time of action is different as 
per different studies. ${ }^{4,26}$ It was found to be at $34+/-6$ seconds by Griffith et al and $50.67+/-7.39$ seconds by Rao et al in the priming group. Contrary to our study, Md. Liaquatunnoor et al did not find any statistically significant difference between the priming and timing technique of intubation $(\mathrm{p}=0.329)$. This may be due to the difference in the anaesthesia protocols as they used Inj. Thiopentone sodium $5.0 \mathrm{mg} / \mathrm{kg}$ as induction agent. $^{28}$ Intubating conditions are dependent on the depth of anaesthesia apart from neuromuscular blockade.

Jose A et al. ${ }^{29}$ found faster onset with priming interval of 4 min while Yavascaoglu B et al. ${ }^{21}$ found satisfactory RSI with rocuronium with 3 minutes priming interval. The differences in priming interval also add to the variations observed in the onset of time of action.

In our study, we assessed intubating conditions with

Cooper et al scoring. None of the patient had poor or minimal jaw relaxation in either group. Intubating scores were 8.67 in group I and 8.77 in group II.

The intubation score was observed when $\mathrm{T}_{1}$ response of TOF was lost. The onset time of intubation was $61.97 \pm 7.84$ sec in group II compared with 114. $57 \pm 15.66$ in group I. Our results were concurrent with the study done by Jeevarathnam $^{31}$ et al, Griffith ${ }^{26}$ et al and $\mathrm{Md}$. Liaquatunnoor $^{28}$ et al who also found no significant difference between the groups in jaw relaxation, vocal cord movement and response to intubation.

In both the group, we got excellent intubating conditions in $97 \%$ of patients and good intubating conditions with $3 \%$ patients. Our result was similar to that of Rao et al. ${ }^{4}$ Our result was also concurrent with the study of Soo Kyung Lee et $\mathrm{al}^{30}$ who observed good-to-excellent intubating conditions in patients getting priming dose of $0.06 \mathrm{mg} / \mathrm{kg}$ of rocuronium bromide follow by administration of the intubating dose of rocuronium bromide $0.54 \mathrm{mg} / \mathrm{kg}$ and in those administered receiving single dose $0.60 \mathrm{mg} / \mathrm{kg}$ of rocuronium bromide.

Our study is also consistent to DS Shashank ${ }^{6}$ et al who compared intubation conditions with pretreatment of rocuronium, vecuronium and atracuronium ion and observed good to excellent intubating conditions within 60 secondswith pretreatment of rocuronium.

$\mathrm{M}$ Hanumantha $\mathrm{Rao}^{4}$ also found that priming with rocuronium produces excellent intubating conditions with onset in $60 \mathrm{sec}$.

In our study no patient had evidence of side effects of priming like weakness, diplopia, dysphagia and dyspnea. The reason for this may be that we used very little priming dose of $0.06 \mathrm{mg} / \mathrm{kg}$. Hanumantha et al also got no side effect while using a priming dose of $0.06 \mathrm{mg} / \mathrm{kg} .{ }^{4}$

\section{Conclusion}

From the study done and data analysed, we conclude that both timing and priming techniques can be used for RSI. Both priming technique and single intubating dose technique provide excellent intubating condition in majority $(97 \%)$ of the patients. With priming technique rapid onset time can be achieved as compared to single intubating dose technique.

Conflict of Interest: None.

\section{References}

1. Sluga M, Ummenhofer W, Studer W, Siegemund M, Marsch SC. Rocuronium versus succinylcholine for rapid sequence induction of anesthesia and endotracheal intubation: a prospective, randomized trial in emergency cases. Anesth Analgesia 2005;101(5):1356- 61.

2. Healy TE, Knight PR, editors. Wylie Churchill - Davidson's A practice of Anesthesia: 7th Edition. CRC Press; 2003 Oct: 585.

3. Sørensen MK, Bretlau C, Gätke MR, Sørensen AM, Rasmussen LS. Rapid sequence induction and intubation with rocuronium- sugammadex compared with succinylcholine: a randomized trial. Br J Anaesth 2012;108(4):682-9.

4. Rao MH, Venkatraman A, Mallleswari R. Comparison of intubating conditions between rocuronium with priming and without priming: Randomized and double-blind study. Indian $J$ Anaesth 2011;55(5):494.

5. Patel D, Upadhyaya R, Kheskani D, Shah P, Kapoor N. Efficacy study on intubating conditions at two different time intervals following rocuronium priming dose in major surgeries: A quasi randomized controlled study. Int J Biomed Res 2014;5(12):758-61.

6. Shashank DS, Singh NR, Singh LK. Effects of pretreatment with different neuromuscular blocking agents on facilitation of intubation with rocuronium: A prospective randomized comparative study. Indian J Anaesth 2014;58(3):303.

7. Ali HH, Utting JE, Gray C. Stimulus frequency in the detection of neuromuscular block in humans. Br J Anesth 1970;42(11):967-78.

8. Frek C, Mitchell VS, McNarry AF. Difficult Airway Society 2015 guidelines for management of unanticipated difficult intubation in adults. Br J Anaesth 2015;115:827-48.

9. Jesse ME, Eva AC, Victoria EF, Nathaniel DM, Warren SS. Modified Rapid Sequence Induction and intubation: A Survey of United States Current Practice. Anaesth Analog 2012;115(1):95-101.

10. El-Kobbia NN, Doghaim MM, Moustafa MA, Deiffallah AM. Comparative study between succinylcholine, rocuronium and magnesium sulphate with rocuronium in rapid sequence induction. Res Opin Anesth Intensive Care 2015;2:57-61

11. Savarese JJ, Caldwell JE, Lien CA, Miller RD. Pharmacology of muscle relaxants and their antagonists. In: Miller, (Editor), 6th ed. Philadelphia Churchill Livingstone; 2004;1:490.

12. Tran DTT, Newton EK, Mount VAH, Lee JS, Wells GA, Perry JJ. Rocuronium versus succinylcholine for rapid sequence induction intubation. Cochrane Database Syst Rev 2015;10. Art. No.: CD002788

13. Venkateswaran R, Chaudhuri S, Deepak KM. Comparison of intubating conditions following administration of low-dose rocuronium or succinylcholine in adults: a randomized double blind study. Anesth Essays Res 2012;6(1).

14. Marsch SC, Steiner L, Bucher E, Pargger H, Schumann M, Aebi T, et al. Succinylcholine versus rocuronium for rapid sequence intubation in intensive care: A prospective, randomized controlled trial. Crit Care 2011;15:R199

15. Chavan SG, Gangadharan S, Gopakumar AK. Comparison of rocuronium at two different doses and succinylcholine for endotracheal intubation in adult patients for elective surgeries. Saudi J Anaesth 2016;10:379-83.

16. Stollings JL, Diedrich DA, Oyen LJ, Brown DR. Rapid sequence intubation: A review of the process and considerations when choosing medications. Ann Pharmacother 2014;48(1):62-76. 
17. Patanwala AE, Stahle SA, Erstad BL. Comparison of succinylcholine and rocuronium for first-attempt intubation success in the emergency department. Acad Emerg Med 2011;18(1):10-4.

18. RC 0781-000.Suggamadex for the reversal of neuromuscular blockade inadult patients: A review of clinical effectiveness and cost effectiveness. Ottawa. Canadian agency for drugs and technologies, 2016.

19. Keating GM. Sugammadex: A review of neuromuscular blockade reversal. Drugs 2016;76:1041-52.

20. Shukla A, Misra S. Ease of intubation: A randomized, doubleblind study to compare two doses of rocuronium bromide for endotracheal intubation. Anesth Essays Res 2016;10:512-5.

21. Yavascaoglu B, Cebelli V, Kelebek N, Uckunkaya N, Kutlay O.Comparison of different priming techniques on the onset time and intubating conditions of rocuronium. Eur J Anaesth 2002;19(7):517-21.

22. Sridhar SK, Lagoo JY, Sathyanarayana PS. A comparative study to evaluate the effects of priming on intubating time and conditions with rocuronium bromide. Karnataka Anaesth $\mathrm{J}$ 2015;1(2):55-9. DOI:10.4103/2394-6954.163077.

23. Chatrath V, Singh I, Chatrath R, Arora N. Comparison of intubating conditions of rocuronium bromide and vecuronium bromide with succinylcholine using "timing principle". $J$ Anaesth Clin Pharmacol 2010;26:493-7.

24. Kwon MA, Song J, Kim JR. Tracheal intubation with rocuronium using a "modified timing principle". Korean J Anesth 2013;64:218-22.

25. Nirmal S, Khalid Z, Lokesh R, Salman M K, Surjya K M, et.al. The Effect of Magnesium Sulphate Pre-Treatment on Rocuronium Priming in Achieving Rapid Onset of Intubating Conditions. J Anest Inten Care Med 2018;6(4):555-693.
26. Griffith KE, Joshi GP, Whitman PF, Garg SA. Priming with rocuronium accelerates the onset of neuromuscular blockade. $J$ Clin Anesth 1997;9(3):204-7.

27. Sudha $P$, Mапju B. Comparison of the effect of two different doses of rocuronium on intubating conditions. Int Surg $J$ 2016;3(2):582-5.

28. Liaquatunnoor Md, Yasmin Rubina, Khatun Shahera UH. A study of priming technique of rocuronium in facilitating intubation. J Bangladesh Soc Anaesth 2008;21(1):3-11.

29. Jose A, Miller R, Rupp S. Refining the priming principle for vecuronium during rapid sequence intubation of anaesthesia. Anaesth 1986;64(2):243-7.

30. Lee SK, Kim JR, Bai SJ. Effects of priming with pancuronium or rocuronium on intubation with rocuroniumin children. Yonsei Med J 1999;40(4):327-30

31. Jeevarathnam R, Solaiappan B. Evaluation of intubating conditions with and without priming dose of rocuronium bromide. J Evolution Med Dent Sci 2016;5(44):2871-6

How to cite this article: Puri A, Dwivedi MB, Bansal S, Tikku S. Effect of priming technique and single intubating dose technique on rapid sequence intubation with rocuronium using train of four monitoring. Indian $J$ Clin Anaesth 2019;6(2):215-19. 